\title{
BIODIVERSITY AND VARIATION IN SPECIES OF THE GENUS MESSOR FOREL, 1890 (HYMENOPTERA, FORMICIDAE) IN THE MEDITERRANEAN PART OF BOSNIA AND HERZEGOVINA
}

\section{Biodiverzitet i varijabilnost vrsta roda Messor forel, 1890 (Hymenoptera, Formicidae) mediteranskog dijela Bosne i Hercegovine}

\author{
Adi Vesnić ${ }^{1}$, Rifat $\breve{S ̌ k r i j e l j}^{1}$
}

\begin{abstract}
Faunistic analysis of the ants in the Mediterranean part of Bosnia and Herzegovina has identified three species of the genus Messor Forel, 1890: $M$. capitatus (Latreille, 1798), M. structor (Latreille, 1798) and M. wasmanni Krausse, 1910. Morphometric analysis of the variability of the worker caste belonging to species of the genus Messor Forel, 1890 in the area of Bosnia and Herzegovina was carried out based on 15 morphometric characters. The analysis of characters provided the description of the local population species: Messor capitatus (Latreille, 1798), $M$. wasmanni Krausse, 1910 and M. structor (Latreille, 1798). The multivariate method, discriminant function analysis established that postpetiole width provides the greatest contribution to interspecies variation. Classification matrices indicate that percentage of correctly classified individuals between three analysed species is $97,3 \%$.
\end{abstract}

Key words: Messor, Formicidae, Bosnia and Herzegovina, variation

\section{INTRODUCTION - Uvod}

Species of the genus Messor Forel, 1890, from the subfamily Myrmicine Lepeletier de Saint Fargeau, 1836, belong to the group of granivorous ants with specialised diet consisting of dominant elements from deserts and dry areas in warm and moderate regions (HÖLLDOBLER \& WILSON, 1990).

Reviews of the ant fauna in the area of western Balkans peninsula have provided data on three species of the genus Messor Forel, 1890: M. capitatus (Latreille, 1798), M. structor (Latreille, 1798) and M. wasmanni Krausse, 1910 (BRAČKo, 2000, 2006, 2007, KARAMAN, 2004; PETROV, 2004; VeSnić, 2011).

Individuals from the genus Messor Forel, 1890 are typical ants of the Mediterranean and Sub-mediterranean area of Bosnia and Herzegovina. However, data

\footnotetext{
${ }^{1}$ Faculty of Natural Sciences and Mathematics, Biology Department
} 
on distribution of species from the genus Messor Forel, 1890 are scarce. On the basis of individual findings we can conclude that species Messor structor (Latreille, 1798) has the widest distribution and appears intermittently in both the Mediterranean area and the xerothermofilic habitats of the Dinaric and Pannonical area of Bosnia and Herzegovina, such a serpentine complexes in the north of the country and thermophilic meadow communities in the central Dinaric area (pers. obs). Species Messor structor (Latreille, 1798) is distributed in the wider area so that individuals of this species were also collected at sites in the central and northern parts of Bosnia such as: Zupca, Breza Municipality, and Oskova Banovici Municipality, which indicates wider distribution of this species in Bosnia and Herzegovina (Adi Vesnic's myrmecological collection).

Species M. capitatus (Latreille, 1798), M. wasmanni Krausse, 1910 have narrow geographic distribution in Bosnia and Herzegovina. It is limited to the Mediterranean area of Herzegovina (ZIMmeRMAnN, 1934).

First record of the species Messor capitatus (Latreille, 1798) in Bosnia and Herzegovina was given for the Hum site, named Messor barbarus subsp. capitatus (Latreille, 1798) var. nigra (Andre) (ZIMmermann, 1934). Species Messor wasmanni Krausse, 1910 was recorded as Messor semirufus subsp. wasmanni Krausse, 1910 at the following sites: Trebinje, Zavala and Mostar (ZIMMERMANN, 1934), while data for species Messor structor (Latreille, 1798) did not exist so far (VESNIĆ, 2011).

Faunistic analysis established that three species of the genus Messor Forel, 1890 in the Mediterranean area of Bosnia and Herzegovina represent sympatric species.

Species identification within genus Messor Forel, 1890 can be done based on the largest specimens of the worker caste - "warriors". However, smaller specimens of the worker caste show significantly lower degree of the interspecies variation, so that due to convergence of character it is not desirable to perform species identification. This paper aims to indicate the degree of intraspecies variation and interspecies difference among three species of the genus Messor Forel, 1890 from the Mediterranean area of Bosnia and Herzegovina, and establish morphometric characters based on which it is possible to carry out species differentiation using the worker caste.

\section{MATERIALS AND METHODS - Materijal i metode rada}

Field research of the myrmecofauna in the wider area of Popovo Polje was carried out in the period from 19 May 2006 to13 September 2009. During the faunistic research of the biodiversity of ants at Popovo Polje, the active method of ant collection was used (AGOSTI ET AL., 2000). Material was identified using different taxonomic keys (Agosti \& Collingwood, 1987; SEIFERT, 2007).

For the purpose of morphometric analysis, individuals were removed from the sample and stored separately in $1.5 \mathrm{ml}$ volume tubes with $96 \%$ ethyl-alcohol. The sample for morphometric analysis, i.e. the sample of 60 individuals of the worker caste, consists of individuals collected at different localities, from different colonies and in different seasons. 
Analysis of 15 morphometric characters was carried out using the Reichert binocular stereomicroscope, with the measuring scale ("Reichert") of 100 points build into the right ocular lens. Morphometric analysis was carried out at two level magnifications, allowing for complete analysis of the morphological structure.

The used characters represent standard measurements in myrmecology as described by Seifert (2007). In addition to standard measurements, four indexes were used to present relative size: Cephalic CI $=\mathrm{HW}^{*} 100 / \mathrm{HL}$, Frontal FI $=\mathrm{EL} / \mathrm{HW} * 100$, Scape SL $=\mathrm{SL}^{*} 100 / \mathrm{HW}$, Petiole PI $=\mathrm{PW}^{*} 100 / \mathrm{HW}$.

Morphometric analysis included 15 characters: 1 . Maximum head length in median line (CL); 2. Maximum cephalic width across eyes (CW); 3. Maximum anterior distance of frontal carinae (FL); 4. Maximum straight line scape length in dorsal view, excluding articular condyle (SL); 5. measured along the maximum diameter of eye (EL); 6. Measured the maximum width of eye (diameter perpendicular to EL) (EW); 7. Mesosoma length measured in lateral view from the anterior pronotal slope to the caudal portion of the propodeum (ML); 8. Propodeal spine length (PSL); 9. Distance between propodeal stigma and posterior line of propodeum (SP); 10. Maximum distance between outer margins of spines (SPW); 11. Maximal length of petiole (PEL); 12. Maximal length of postpetiole measured in dorsal view (PPL); 13. Maximum width of petiole (PEW); 14. Maximum width of postpetiole (PPW); 15. Length of hind femora (LHF) (SEIFERT, 2007). Statistical analysis included descriptive and canonical discriminant analysis. Differences between groups were tested by ANOVA test in Statistica 8 and Past programs.

\section{RESULTS AND DISCUSSION - Rezultati rada i diskusija}

During the faunistic research in the wider area of Popovo Polje involving species Messor capitatus (Latreille, 1798), 513 individuals were collected at 12 sites. At Popovo Polje, 784 individuals of the worker caste of the species Messor wasmanni Krausse, 1910 were collected at 11 sites. During the faunistic research, 367 individuals of the worker caste of the species Messor structor (Latreille, 1798) were collected at six sites; these are representing the first record of the species in Bosnia and Herzegovina.

Based on the analysis of 15 morphometric characters, statistical description of the population species of genus Messor Forel, 1890 from Popovo Polje was carried out (Table 1.).

In case of the species Messor capitatus (Latreille, 1798), the highest degree of variation was found regarding eye width (EW), and the lowest regarding maximum distance between outer margins of spines (SPW) (Table 1.). In case of the species Messor wasmanni Krausse, 1910, the highest degree of variation was found regarding anterior distance of frontal carinae (FL), and the lowest coefficient of variation value found regarding eye width (EW).

In case of species Messor structor (Latreille, 1798) the greatest variation in terms of 15 morphometric characters was found regarding propodeal spine length 
(PSL), while the lowest coefficient of variation value was found regarding length of hind femora (LHF) (Table 1.).

Relation of individual measurements, presented through five morphometric indexes, has noted a relation of length measurements of the analysed species (Table 2.). For species Messor capitaus (Latreille, 1798) average value of the Cephalic index is (CI=98), which represents a slightly lower value in comparison with species Messor structor (Latreille, 1798) with $(\mathrm{CI}=101)$ and Messor wasmanni Krausse, 1910 with $(\mathrm{CI}=104)$ (Table 2.). ANOVA test results indicate that differences between three Messor Forel, 1890 species are statistically significant at $5 \%$ level based on seven morphmetric characters.

Table 1. Overview of variation of the selected morphometric characters among the species of genus Messor Forel, 1890, of the local population from Popovo Polje, average \pm standard deviation, (min-max), coefficient of variation (V\%)

Tabela 1. Pregled variranja odabranih morfometrisjkih karaktera između vrsta iz roda Messor Forel, 1890 lokalnih populacija sa Popovog polja, srednja vrijednost土standardna devijacija, (min-max), koeficijent varijabilnosti (V\%)

\begin{tabular}{|c|c|c|c|c|c|c|}
\hline \multirow{2}{*}{$\begin{array}{l}\text { Variable } \\
1 . \quad \mathrm{CW}\end{array}$} & \multicolumn{2}{|c|}{ M. capitatus $\mathrm{N}=60$} & \multicolumn{2}{|c|}{ M. wasmanni $\mathrm{N}=60$} & \multicolumn{2}{|c|}{ M. structor $\mathrm{N}=60$} \\
\hline & $\begin{array}{c}1.79 \pm 0.62 \\
(0.94-3.37)\end{array}$ & $\mathrm{V} \%=34.69$ & $\begin{array}{c}1.79 \pm 0.43 \\
(1.05-2.62)\end{array}$ & $\mathrm{V} \%=24.20$ & $\begin{array}{c}1.65 \pm 0.45 \\
(0.89-2.41)\end{array}$ & $\mathrm{V} \%=27.00$ \\
\hline 2. $\mathrm{CL}$ & $\begin{array}{c}1.80 \pm 0.53 \\
(0.98-3.18)\end{array}$ & $\mathrm{V} \%=29.47$ & $\begin{array}{c}1.72 \pm 0.36 \\
(1.08-2.39)\end{array}$ & $\mathrm{V} \%=21.14$ & $\begin{array}{c}1.62 \pm 0.37 \\
(0.96-2.25)\end{array}$ & $\mathrm{V} \%=22.89$ \\
\hline 3. EL & $\begin{array}{c}0.34 \pm 0.08 \\
(0.21-0.65)\end{array}$ & $\mathrm{V} \%=24.26$ & $\begin{array}{c}0.32 \pm 0.06 \\
(0.16-0.44)\end{array}$ & $\mathrm{V} \%=18.14$ & $\begin{array}{l}0.32 \pm 0.064 \\
(0.21-0.45)\end{array}$ & $\mathrm{V} \%=20.00$ \\
\hline 4. EW & $\begin{array}{c}0.40 \pm 0.15 \\
(0.19-0.82)\end{array}$ & $\mathrm{V} \%=38.05$ & $\begin{array}{c}0.25 \pm 0.04 \\
(0.14-0.33)\end{array}$ & $\mathrm{V} \%=15.78$ & $\begin{array}{c}0.24 \pm 0.05 \\
(0.16-0.33)\end{array}$ & $\mathrm{V} \%=19.33$ \\
\hline 5. FL & $\begin{array}{c}0.51 \pm 0.16 \\
(0.28-0.89)\end{array}$ & $\mathrm{V} \%=30.76$ & $\begin{array}{c}0.50 \pm 0.12 \\
(0.19-0.70)\end{array}$ & $\mathrm{V} \%=24.68$ & $\begin{array}{c}0.46 \pm 0.11 \\
(0.26-0.65)\end{array}$ & $\mathrm{V} \%=23.57$ \\
\hline 6. SL & $\begin{array}{c}1.49 \pm 0.35 \\
(0.91-2.27) \\
\end{array}$ & $\mathrm{V} \%=23.14$ & $\begin{array}{c}1.42 \pm 0.26 \\
(0.94-1.92) \\
\end{array}$ & 18.14 & $\begin{array}{c}1.50 \pm 0.29 \\
(0.96-1.92) \\
\end{array}$ & $\mathrm{V} \%=19.43$ \\
\hline 7. $\mathrm{ML}$ & $\begin{array}{c}2.14 \pm 0.50 \\
(1.29-3.18)\end{array}$ & $\mathrm{V} \%=23.54$ & $\begin{array}{c}2.08 \pm 0.41 \\
(1.31-2.83)\end{array}$ & $\mathrm{V} \%=19.86$ & $\begin{array}{c}2.02 \pm 0.41 \\
(1.29-2.71)\end{array}$ & $\mathrm{V} \%=20.22$ \\
\hline 8. PSL & $\begin{array}{c}0.21 \pm 0.05 \\
(0.09-0.33)\end{array}$ & $\mathrm{V} \%=26.55$ & $\begin{array}{c}0.19 \pm 0.04 \\
(0.12-0.28)\end{array}$ & $\mathrm{V} \%=22.67$ & $\begin{array}{c}0.18 \pm 0.06 \\
(0.09-0.42)\end{array}$ & $\mathrm{V} \%=34.10$ \\
\hline 9. SPW & $\begin{array}{c}0.30 \pm 0.06 \\
(0.19-0.44)\end{array}$ & $\mathrm{V} \%=21.06$ & $\begin{array}{c}0.33 \pm 0.07 \\
(0.21-0.49)\end{array}$ & $\mathrm{V} \%=21.27$ & $\begin{array}{c}0.26 \pm 0.06 \\
(0.16-0.42)\end{array}$ & $\mathrm{V} \%=22.77$ \\
\hline 10. SP & $\begin{array}{c}0.28 \pm 0.07 \\
(0.14-0.47)\end{array}$ & V\% & $\begin{array}{c}0.30 \pm 0.07 \\
(0.19-0.42)\end{array}$ & 22.21 & $\begin{array}{c}0.24 \pm 0.06 \\
(0.12-0.35)\end{array}$ & 25.26 \\
\hline 11. PL & $\begin{array}{c}0.59 \pm 0.14 \\
(0.33-0.89)\end{array}$ & $\mathrm{V} \%=23.54$ & $\begin{array}{c}0.70 \pm 0.14 \\
(0.40-0.94)\end{array}$ & $\mathrm{V} \%=19.43$ & $\begin{array}{c}0.58 \pm 0.13 \\
(0.30-0.87)\end{array}$ & $\mathrm{V} \%=22.83$ \\
\hline 12. PW & $\begin{array}{c}0.38 \pm 0.08 \\
(0.21-0.56)\end{array}$ & $\mathrm{V} \%=22.03$ & $\begin{array}{c}0.35 \pm 0.07 \\
(0.21-0.49)\end{array}$ & $\mathrm{V} \%=19.88$ & $\begin{array}{c}0.31 \pm 0.07 \\
(0.19-0.44)\end{array}$ & $\mathrm{V} \%=23.02$ \\
\hline 13. PPL & $\begin{array}{c}0.39 \pm 0.08 \\
(0.26-0.56)\end{array}$ & $\mathrm{V} \%=21.52$ & $\begin{array}{c}0.37 \pm 0.07 \\
(0.26-0.51)\end{array}$ & $=19.22$ & $\begin{array}{c}0.36 \pm 0.08 \\
(0.21-0.51)\end{array}$ & $\mathrm{V} \%=21.80$ \\
\hline 14. PEW & $\begin{array}{c}0.41 \pm 0.11 \\
(0.26-0.65)\end{array}$ & $\mathrm{V} \%=25.57$ & $\begin{array}{c}0.42 \pm 0.08 \\
(0.26-0.56)\end{array}$ & $\mathrm{V} \%=19.81$ & $\begin{array}{c}0.43 \pm 0.10 \\
(0.28-0.61)\end{array}$ & $\mathrm{V} \%=22.85$ \\
\hline 15. LHF & $\begin{array}{c}1.94 \pm 0.45 \\
(1.15-2.97)\end{array}$ & $\mathrm{V} \%=23.23$ & $\begin{array}{c}1.77 \pm 0.34 \\
(1.10-2.43)\end{array}$ & $\mathrm{V} \%=19.22$ & $\begin{array}{c}1.79 \pm 0.33 \\
(1.12-2.32)\end{array}$ & $\mathrm{V} \%=18.58$ \\
\hline
\end{tabular}


Table 2. Overview of variation of the selected morphometric indexes for three species of genus Messor Forel, 1890 from Popovo Polje: min-average-max

Tabela 2. Pregled variranja odabranih morfometrijskih indeksa za tri vrste iz roda Messor Forel, 1890 sa Popovog polja: min-srednja vrijednost-max

\begin{tabular}{|c|c|c|c|}
\hline Variable & $\begin{array}{c}\text { Messor capitatus } \\
\text { (Latreille) }\end{array}$ & $\begin{array}{c}\text { Messor } \\
\text { structor (Latreille) }\end{array}$ & $\begin{array}{c}\text { Messor wasmanni } \\
\text { Krausse }\end{array}$ \\
\hline $\mathrm{CI}$ & 79-98-119 & 92-101-112 & 92-104-117 \\
\hline FI & $12-20-26$ & $17-20-26$ & $15-18-23$ \\
\hline SI & 65-87-102 & 70-93-108 & 68-80-91 \\
\hline PI & $16-22-30$ & $9-19-23$ & $14-20-25$ \\
\hline PPI & $19-24-46$ & $21-26-32$ & $19-24-29$ \\
\hline
\end{tabular}

Analysis of variance between analysed species indicate statistically significant differences at level of $5 \%(\mathrm{p}<0,05)$. Statistically significant differences between groups were also detected with MANOVA analysis $(\mathrm{p}<0,0001)$.

Discriminant function analysis has established that postpetiole width (PPW) has the greatest discriminant potential, with the Partial Wilks' Lambda value of 0.697566 (Table 3.).

Table 3. Discriminant Function Analysis Summary Wilks' Lambda: .05007; F (30.326)=37.699 $\mathrm{p}<0,0000$

Tabela. 3. Sumirani podaci analize diskriminantne funkcije Wilks' Lambda: .05007; F (30.326) $=37.699 p<0,0000$

\begin{tabular}{|l|l|l|l|l|l|l|}
\hline N=180 & $\begin{array}{c}\text { Wilks' } \\
\text { lambda }\end{array}$ & $\begin{array}{c}\text { Partial } \\
\text { Wilks' } \\
\text { lambda }\end{array}$ & F-remove & p-level & Toler. & \multicolumn{1}{|c|}{ 1-Toler. } \\
\hline HW & 0.056925 & 0.879492 & 11.16715 & 0.000029 & 0.013302 & 0.986699 \\
\hline HL & 0.054650 & 0.916112 & 7.46295 & 0.000792 & 0.018259 & 0.981741 \\
\hline EW & 0.061495 & 0.814134 & 18.60633 & 0.000000 & 0.480599 & 0.519401 \\
\hline SL & 0.069763 & 0.717648 & 32.06537 & 0.000000 & 0.024420 & 0.975580 \\
\hline PSL & 0.053261 & 0.939992 & 5.20283 & 0.006451 & 0.221954 & 0.778046 \\
\hline SPW & 0.055463 & 0.902682 & 8.78654 & 0.000238 & 0.107433 & 0.892567 \\
\hline PL & 0.061730 & 0.811040 & 18.98832 & 0.000000 & 0.152617 & 0.847383 \\
\hline SP & 0.060568 & 0.826591 & 17.09772 & 0.000000 & 0.180222 & 0.819778 \\
\hline PW & 0.052858 & 0.947172 & 4.54557 & 0.011994 & 0.115241 & 0.884759 \\
\hline PPW & 0.071771 & 0.697566 & 35.33482 & 0.000000 & 0.074435 & 0.925565 \\
\hline LHF & 0.058014 & 0.862991 & 12.93901 & 0.000006 & 0.020956 & 0.979044 \\
\hline
\end{tabular}

Table 4. Chi-Square Tests with Successive Roots Removed

Tabela 4. Hi-kvadrat test za dva korjena

\begin{tabular}{|l|l|l|l|l|c|c|}
\hline \multirow{4}{*}{$\begin{array}{c}\text { Roots } \\
\text { Removed }\end{array}$} & \multicolumn{1}{|c|}{ Eigen- } & \multicolumn{1}{|c|}{ Canonicl } & Wilks' & Chi-Sqr. & df & p-level \\
\cline { 2 - 7 } & 4.431717 & 0.903270 & 0.050065 & 509.0528 & 30 & 0.00 \\
\hline 1 & 2.677278 & 0.853264 & 0.271940 & 221.3694 & 14 & 0.00 \\
\hline
\end{tabular}


Both discriminant functions roots are statistically significant (Table 4.). The first discriminant function discriminates mostly between the Messor wasmanni Krausse, 1910 and the other two Messor Forel, 1890 species. The second discriminant function seems to distinguish mostly between Messor capitatus (Latreille, 1798) and the other Messor Forel, 1890 species (Tab. 5.).

Table 5. All Groups Means of Canonical Variables

Tabela 5. Srednja vrijednost centroida

\begin{tabular}{|l|l|l|}
\hline \multicolumn{1}{|c|}{ Group } & \multicolumn{1}{c|}{ Root 1 } & \multicolumn{1}{c|}{ Root 2 } \\
\hline Messor capitatus & 0.17178 & -2.29074 \\
\hline Messor wasmanni & -2.63827 & 1.02974 \\
\hline Messor structor & 2.46649 & 1.26100 \\
\hline
\end{tabular}

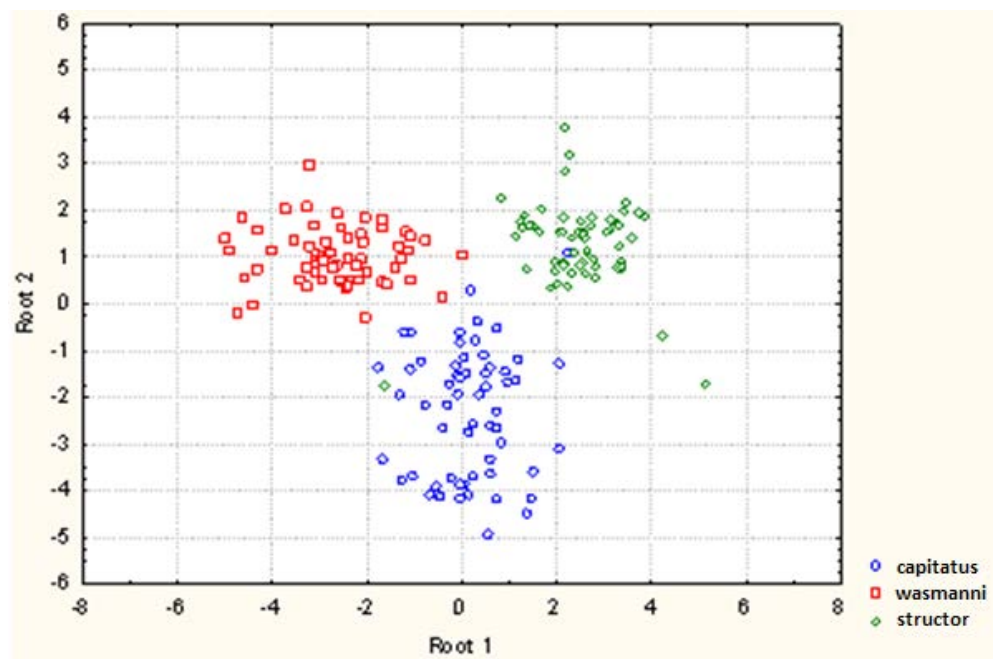

Graph 1. Biplot for two roots Root 1vs. 2 for two species of the genus Messor: M. capitatus blue circles, $M$. wasmanni red squares and $M$. structor green diamonds

Grafikon 1. Biplot za dva korjena Root 1vs. 2 za vrste iz roda Messor: M. capitatus plavi krug, M. wasmanni crveni kvadratići i M. structor zeleni dijamant

Statistical classification of 180 individuals from worker caste of the three species of genus Messor Forel, 1890 found that an overall percentage of accurately classified individuals from worker caste was 97.3\%. In case of the species Messor wasmanni Krausse, 1910 and Messor structor (Latreille, 1798), the success rate was 98.4\%. The smallest percentage of classification was found regarding species Messor capitatus (Latreille, 1798) with 95.0\% percentage. Two individuals from worker cast of the species Messor capitatus (Latreille, 1798) were classified as Messor structor (Latreille, 1798) and one as Messor wasmanni Krausse, 1910 (Table 6.). 
Table 6. Classification Matrix Rows: Observed classifications; Columns: Predicted classifications

Tabela 6. Klasifikacioni matriks redovi: redovi utvrđena klasifikacija; kolone pretpostavljena klasifikacija

\begin{tabular}{|c|c|c|c|c|}
\hline & & \multicolumn{3}{|c|}{ Absolute number of classified individuals } \\
\hline Group & Percent & Messor capitatus & Messor wasmanni & Messor structor \\
\hline Messor capitatus & $95.0 \%$ & 57 & 1 & 2 \\
\hline Messor wasmanni & $98.4 \%$ & 0 & 59 & 1 \\
\hline Messor structor & $98.4 \%$ & 1 & 0 & 59 \\
\hline Total & $\mathbf{9 7 . 3 \%}$ & $\mathbf{5 8}$ & $\mathbf{6 0}$ & $\mathbf{6 2}$ \\
\hline
\end{tabular}

\section{CONCLUSION - Zakljičak}

Faunistic research in the wider area of Popovo polje established presence of three species of genus Messor Forel, 1890 in Bosnia and Herzegovina: Messor capitatus (Latreille, 1798), Messor wasmanni Krausse, 1910 and Messor structor (Latreille, 1798).

Descriptive statistical analysis of the variations among the worker caste of the three species of genus Messor Forel, 1890 noted the highest degree of variation in species M. capitatus (Latreille, 1798) with eye width (EW) V\% $=38.05$.

In terms of Messor wasmanni Krausse, 1910, the highest coefficient of variation value $\mathrm{V} \%=24.68$ was found regarding anterior distance of frontal carinae (FL).

The highest degree of variation in species Messor structor (Latreille, 1798) was found regarding propodeal spine lenght (PSL) V\%=34.10.

Multivariate discriminant function analysis based on 15 morphometric characters found that postpetiole width (PPW) has the greatest discriminant potential.

Statistical classification of 180 individuals from worker caste of the three species of genus Messor Forel, 1890 found that the overall percentage of accurately classified individuals from worker caste was $97.3 \%$.

\section{LITERATURE - Literatura}

Agosti, D., Collingwood, C. A. (1987): A provisional list of the Balkan ants (Hym. Formicidae) with a key to the worker caste. II. Key to the worker caste, including the European species without the Iberian. Mitteilungen der Schweizerischen Entomologischen Gesellschaft, 60: 261-293.

Agosti, D., Majer, J., Alonso, E.; Schultz, T.R. (Eds.) (2000): Sandard Methods for Measuring and Monitoring Biodiversity. Smithsonian Institution Press, Washington D.C., 
BRAČKo, G. (2000): Review of the Ant Fauna (Hymenoptera: Formicidae) of Slovenia. Acta Biologica Slovenica, 43(4): 3-54.

BRAČKO, G. (2006): Review of the Ant Fauna (Hymenoptera: Formicidae) of Croatia. Acta Biologica Slovenica, 14(2): 131-156.

BRAČKo, G. (2007): Checklist of the ants of Slovenia (Hymenoptera: Formicidae). Natura Sloveniae, 9(1): 15-24.

HÖlldobler, B., Wilson, E. O. (1990): The Ants. Belknap Press, Cambridge, MA.

Karaman, M. (2004): Checklist of known species of Ants (Hymenoptera, Formicidae) in the fauna of Montenegro. Natura Montenegrina, 3: 83-92.

Petrov, Z. I. (2004): A list of currently known Ant species (Formicidae, Hymenoptera) of Serbia. Arch. Biol. Sci., Belgrade, 56(3-4): 121-125.

SEIFERT, B. (2007): Ameisen Mittel- und Nordeuropas. Tauer: lutra Verlags - und Vertreibsgesellschaft, 368 pp.

VESNIĆ, A. (2011): Revised systematic list of ants of Bosnia and Herzegovina. In: Lelo, S. (ed.): Fauna of Bosnia and Herzegovina - A biosystematic review. 7th amended and updated internal edition of Society for Inventarisation and protection of animals, Ilijaš, Canton Sarajevo, pp: 205-207.

ZimmermanN, S. (1934): Beitrag zur kenntnis der Ameisenfauna Suddalmatiens. Erhandlungen der Zool.-Botan. Geselschaft, Wien, 84(1-4): 1-65.

\section{SAŽETAK}

Klasična determinacija vrsta iz roda Messor primarno se vrši na osnovu jedinki iz kaste krupnih radnika. Zbog preklapanja karaktera kod sitnih radnika determinacija vrsta iz roda Messor se ne prakticira. Cilj morfometrijske analize u radu je utvrditi stepen intra $\mathrm{i}$ interspecijske varijabilnosti u svrhu određivanja stepena sličnosti sitnih radnika. U svrhu analize korištena je visoko precizna morfometrija zasnovana na analizi 15 egzomorfoloških parametara. Multivarijantnom statističkom analizom rezultati za tri vrste iz navedenog roda su obrađeni i utvrđena je statistički značajna razlika između vrsta. Ukupan stepen pogrešno grupiranih individual je $2,7 \%$ od ukupnog uzorka. Greška u klasifikaciji manja od 5\% ukazuje da korištenje morfometrijske analize u cilju determinacije polimorfnih vrsta može da doprinese sigurnosti determinacije i u slučaju kada se radi o jedinkama koje je subjektivnim metodama teško determinirati. 


\title{
ECOLOGICAL STATUS OF RIVERS DRINJAČA
}

\section{Ekološki status rijeke Drinječe}

\author{
Ramiz Salkić ${ }^{1}$, Sadbera Trožić-Borovac ${ }^{2}$, Mehdin Selimović $^{1}$, Rifat Škrijelj ${ }^{2}$, \\ Dubravka Hafner ${ }^{3}$
}

\begin{abstract}
More and more intensive unplanned use of water resources in Europe and beyond, have turned the efforts for stopping exploitation and reduction of available freshwater ecosystems. According to the provisions of the Water Framework Directive (WFD), biotic parameters, especially the benthos organisms (zoological component) gives the greatest significance in the appropriate way of identifying the ecological status and typology. This paper presents the application of different biotic indices in assessing the ecological status of the river Drinjača. The analysis reveals a high diversity in the composition of phytobenthos and macrozoobenthos with domination of preimaginal stage of aquatic insects. Acoording to the indices applied, water of the river Drinjača at locations upstream and downstream of the confluence of Jadar is oligo to betamesosaprobic. A high ecological status has been determined by applying biotic indices on the macrozoobenthos composition ehich takes this part of the stream as referent to all other waterstreams of the same type on the territory of Bosnia and Herzeogovina.
\end{abstract}

Key Words: typology, degradation, freshwater ecosystems, bioticindices, macrozoobenthos

\section{INTRODUCTION - Uvod}

In recent decades, we have witnessed the increased concern about the environmental problems produced by anthropogenic degradation and misuse of natural resources.

Policy regarding the correct use of water is extremely important because the availability of clean freshwater resources is essential for life throughout the planet.

\footnotetext{
${ }^{1}$ Faculty of Natural Sciences and Mathematics, Biology Department, Tuzla

${ }^{2}$ Faculty of Natural Sciences and Mathematics, Biology Department, Sarajevo

${ }^{3}$ University of Mostar
} 